\title{
Evidence based models of care for the treatment of alcohol use disorder in primary health care settings: a systematic review
}

Susan A. Rombouts ${ }^{1}$, James H. Conigrave ${ }^{2}$, Richard Saitz ${ }^{3}$, Eva Louie ${ }^{1}$, Paul Haber ${ }^{1,4}$ and Kirsten C. Morley ${ }^{1 *}$ (1)

\begin{abstract}
Background: Pharmacological and behavioural treatments for alcohol use disorders (AUDs) are effective but the uptake is limited. Primary care could be a key setting for identification and continuous care for AUD due to accessibility, low cost and acceptability to patients.

We aimed to synthesise the literature regarding differential models of care for the management of AUD in primary health care settings.

Methods: We conducted a systematic review of articles published worldwide (1998-present) using the following databases; Medline, PsycINFO, Cochrane database of systematic reviews, Cochrane Central Register of Controlled Trials and Embase. The Grey Matters Tool guided the grey literature search. We selected randomised controlled trials evaluating the effectiveness of a primary care model in the management of AUD. Two researchers independently assessed and then reached agreement on the included studies. We used the Cochrane risk of bias tool 2.0 for the critical appraisal.

Results: Eleven studies (4186 participants) were included. We categorised the studies into 'lower' versus 'higher' intensity given the varying intensity of clinical care evaluated across the studies. Significant differences in treatment uptake were reported by most studies. The uptake of AUD medication was reported in 5 out of 6 studies that offered AUD medication. Three studies reported a significantly higher uptake of AUD medication in the intervention group. A significant reduction in alcohol use was reported in two out of the five studies with lower intensity of care, and three out of six studies with higher intensity of care.

Conclusion: Our results suggest that models of care in primary care settings can increase treatment uptake (e.g. psychosocial and/or pharmacotherapy) although results for alcohol-related outcomes were mixed. More research is required to determine which specific patient groups are suitable for AUD treatment in primary health care settings and to identify which models and components are most effective.
\end{abstract}

Trial Registration: PROSPERO: CRD42019120293.

Keywords: Alcohol use disorder, Treatment, Primary health care, General practice, Pharmacotherapy

\footnotetext{
* Correspondence: kirsten.morley@sydney.edu.au

'Discipline of Addiction Medicine, Central Clinical School, Sydney Medical

School, Faculty of Medicine and Health, The University of Sydney, Sydney, NSW 2006, Australia

Full list of author information is available at the end of the article
}

C C The Author(s). 2020 Open Access This article is licensed under a Creative Commons Attribution 4.0 International License, which permits use, sharing, adaptation, distribution and reproduction in any medium or format, as long as you give appropriate credit to the original author(s) and the source, provide a link to the Creative Commons licence, and indicate if changes were made. The images or other third party material in this article are included in the article's Creative Commons licence, unless indicated otherwise in a credit line to the material. If material is not included in the article's Creative Commons licence and your intended use is not permitted by statutory regulation or exceeds the permitted use, you will need to obtain permission directly from the copyright holder. To view a copy of this licence, visit http://creativecommons.org/licenses/by/4.0/ The Creative Commons Public Domain Dedication waiver (http://creativecommons.org/publicdomain/zero/1.0/) applies to the data made available in this article, unless otherwise stated in a credit line to the data. 


\section{Background}

Alcohol use disorder (AUD) is highly prevalent and contributes to $4 \%$ of the global disease burden and $5.3 \%$ of mortality worldwide [1]. Effective and safe treatments are available but are underutilised [2, 3]. For example, it is estimated that only $3 \%$ of AUD patients receive approved pharmacotherapy in Australia [4, 5]. In the USA, only $2.1 \%$ of a cohort with AUD were found to have been prescribed alcohol pharmacotherapy [6]. Moreover, time between onset of the disorder and initial treatment can be decades [2, 7].

Only 1 in 10 individuals with AUD perceive a need for treatment which possibly contributes to the low rate of enrolment and high dropout in specialty care [8]. Patients that do specifically seek AUD treatment are likely to be those with severe conditions, including greater alcohol intake and concurrent mental and physical comorbidity [3]. However, a significant proportion of AUD patients access primary health care, albeit for other reasons [9], and this represents an opportunity for earlier intervention. Primary health care appears to be an ideal treatment setting for AUD due to this accessibility but also due to low costs and acceptability for patients.

Primary care settings are able to provide longitudinal, comprehensive and coordinated care with medication management [10]. Patients commonly present to primary care for problems related to AUD such as mood disorders, hypertension, injuries and others. The chronic and relapsing nature of some with AUD make this type of care appropriate and necessary. Indeed, while the rate of prescribing of AUD pharmacotherapy is low, one recent study demonstrated that clients who had more contact with the primary care system were more likely to be prescribed AUD medications [6]. Identifying and treating early-stage AUD in these settings can potentially prevent conditions deteriorating.

In recent years, several models of care have been evaluated in primary care settings. The 'screening, brief intervention and referral to specialty care (SBIRT)' model is best known and multiple systematic reviews confirm its effectiveness [11-13]. However, in the management of moderate-severe AUD, the effectiveness of SBIRT is limited at best $[3,14,15]$. Integrated models of care or pathways have been developed, whereby the treatment is delivered either by the general practitioner or an on-site nurse practitioner.

Accordingly, we aimed to synthesise the existing models of care, other than SBIRT, for the management of AUD in primary care settings. We sought to evaluate the effectiveness of these care models with regards to increasing treatment engagement (e.g. number of visits and/or uptake of AUD pharmacotherapy) and reducing alcohol consumption and to provide recommendations for further research.

\section{Methods}

We followed the Preferred Reporting Items for Systematic Reviews and Meta-analyses (PRISMA) guidelines for systematic reviews [16]. We registered the systematic review with the international Prospective Register of Systematic reviews (PROSPERO: CRD42019120293). Additional information on the methods can be found in the published protocol [17].

\section{Eligibility criteria}

Studies were eligible if: 1) they were published in English, 2) they were published after 1 January 1998 (to allow for a 20 year period from search commencement), 3 ) they compared models for the management of AUD, and 4) at least $80 \%$ or more of the subjects had an AUD, or if results for subjects with AUD were presented separately to those with other conditions. We excluded languages other than English given the costs and time required for translation were unavailable.

Our interventions of interest are complex health interventions which target how care is organised in addition to types of treatments. For inclusion, the model of care had to cover several parts of the care pathway other than screening. The setting had to be in primary health care using primary care physicians, nurse practitioners and/ or case managers. Consultations with specialty care was accepted. Treatment facilities had to be physically in or attached to the primary care clinic. We excluded studies where the independent variable was the specific treatment rather than the model of care. We also excluded articles examining SBIRT (screening, brief intervention, referral to treatment) for individuals with mild AUD unless a novel component was added to the model of care.

\section{Search strategy}

We searched Medline, PsycINFO, Cochrane database of systematic reviews, Cochrane Central Register of Controlled Trials (CENTRAL) and Embase (2019). We conducted reference searches of relevant reviews and articles. Grey Matters tool, which is a checklist of health-related sites organized by topic, and Google were used in the grey literature search. Authors of identified conference abstracts were contacted for additional information about their study and potential availability of preliminary data. Before publication of this systematic review we ran the search again to include all newly published studies (04/06/2020).

See Appendix 1 for our search strategy in Medline and Appendix 2 for grey literature.

\section{Study selection}

Initially, duplicates were removed from the database after which all the titles were screened with the purpose of discarding irrelevant articles (unrelated to alcohol 
treatment or primary care). The remaining papers were included in an abstract and full-text screen. All steps were completed by one researcher (SR) with consultation with two other researchers (KM and JC). Disagreements were resolved in consensus-based discussion.

\section{Data extraction and synthesis}

Key information extracted from the articles included design of the study; type of participants; study setting; type of intervention/ model of care; type of health care worker; duration of follow-up and outcome measures. Outcome data on treatment engagement (e.g. number of visits and/ or uptake of AUD pharmacotherapy or any treatment) and alcohol use were extracted. Categorical outcomes were converted into log odds ratios (OR) and log incidence rate ratios (IRR). Continuous measures were converted into standardized mean differences (SMD). Data extraction was completed by one researcher (SR) with error checking by two other researchers (JC and KM). Due to variability in study design, measures and outcome data reporting, we were unable to extract sufficient data to perform a meta-analytic synthesis.

\section{Quality appraisal}

All studies were critically assessed by two researchers independently using the Revised Cochrane risk-of-bias tool
(RoB 2.0) [18]. Meta-biases such as outcome reporting bias was evaluated by determining whether the protocol was published before recruitment of patients. Additionally, trial registries were checked to determine whether the reported outcome measures and statistical methods matched original protocols. We also reported on funding from the pharmaceutical industry. To minimise publication bias, we looked at conference abstracts and grey literature.

\section{Results}

The literature search including synonyms for 'model of care' returned 1060 records. An additional 71 records were identified from other sources (Fig. 1). The details of the included studies $(n=11)$ are summarised in Table 1 according to intensity and/or duration of care (from low to high).

\section{Population}

This systematic review included 11 studies with a combined number of 4186 participants ( $72 \%$ male). Identification of hazardous alcohol use or AUD differed among the studies, ranging from utilizing assessment tools to more formal diagnosis of AUD using the International Statistical Classification of Diseases (10th revision) (ICD-10) or according to the Diagnostic and Statistical Manual of Mental Disorders (DSM-IV) criteria for current alcohol dependence. The

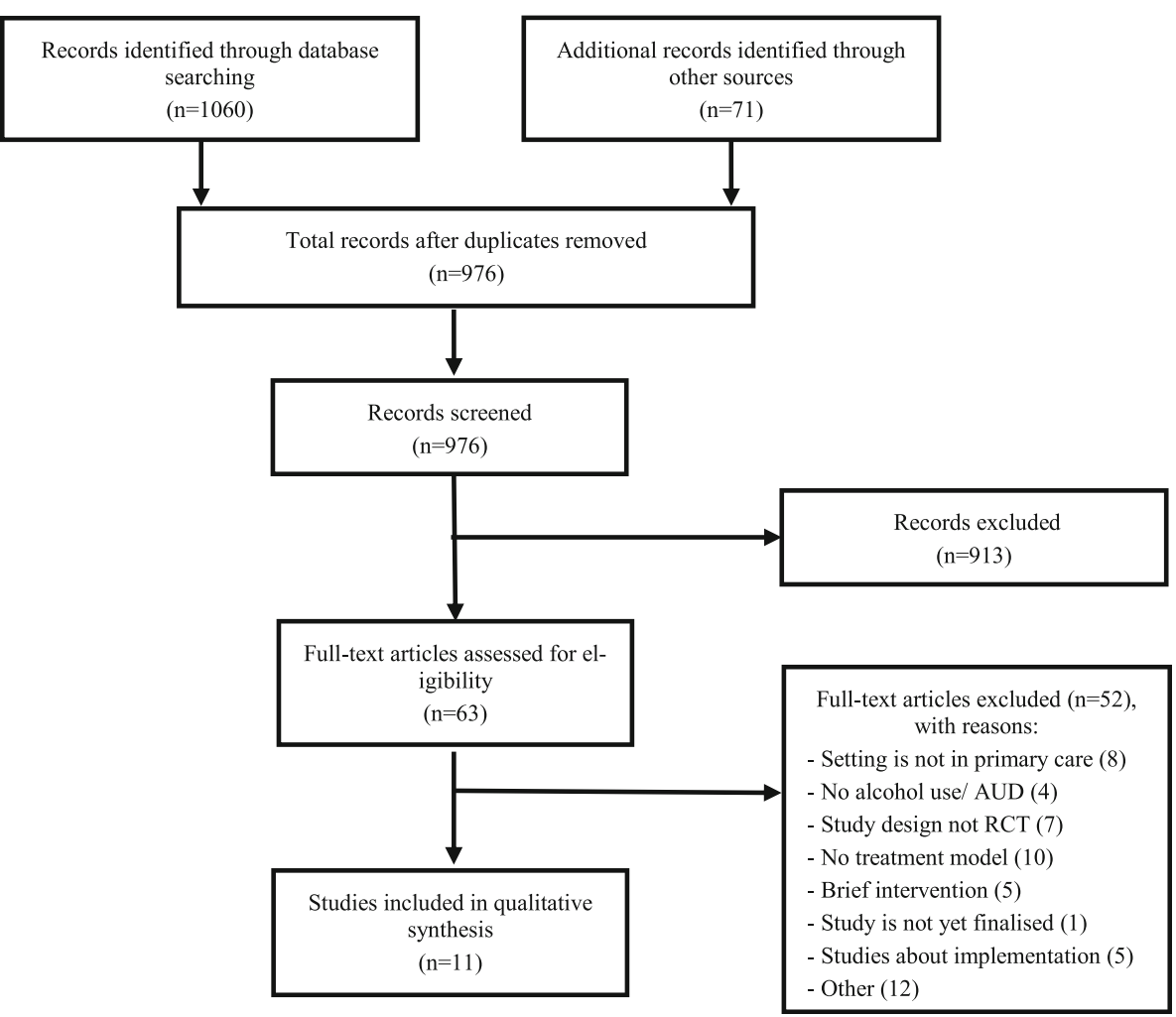

Fig. 1 Flow diagram of the study selection process 
Table 1 Study characteristics

\begin{tabular}{llll}
\hline Study, year & $\begin{array}{l}\text { Design, study } \\
\text { duration }\end{array}$ & $\begin{array}{l}\text { Setting (country; } \\
\text { type of health } \\
\text { care } \\
\text { professional) }\end{array}$ & $\begin{array}{l}\text { Participants (inclusion criteria + } \\
\text { recruitment details) }\end{array}$ \\
\hline
\end{tabular}

Low intensity models of care

Moore et al., RCT

2010 [19] 12 months

Ettner et al., RCT (cluster)

2014 [20] 12 months

\begin{abstract}
Wallhed
Finn et al.,

$\mathrm{RCT}$

6 months
\end{abstract}

2018 [21]

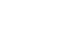

Drummond $\mathrm{RC}$

et al., 20096 months

[22]

United Kingdom

Community

based PC clinics

United States

Community

based PC clinics

$\geq 60$ years, at risk drinkers identified by the CARET $(n=1186)$

Recruitment: in primary care (not seeking treatment for AUD)

$\geq 18$ years, Alcohol dependence according to ICD-10.

$(n=288)$

Recruitment: in primary care (not seeking treatment for AUD) + via advertisement in newspapers (seeking treatment for AUD)

Men, age $\geq 18$ years, AUDIT $\geq 8$ and/or diagnosis of AUD using ICD-10 criteria and/ or $>21 \mathrm{SD} /$ week or $>8 \mathrm{SD} /$ day $(n=112)$ Recruitment: in primary care (not seeking treatment for AUD)

$\geq 55$ years, AUDIT $\geq 8(n=529)$

Recruitment: in primary care (not seeking treatment for AUD)

\section{Multifaceted intervention:}

Personalized patient reports (educational booklet; a drinking diary). Drinking risk reports for physicians to guide drinking discussion. Telephone behavioural counselling 3x (at 2, 4 , 8 weeks)

Control group:

Usual PC + a booklet outlining recommended behaviours for alcohol use, nutrition, exercise, medication use and smoking.

\section{Educational intervention:}

Emailed personalized patient report (educational booklet; a drinking diary; 13 tips sheets) at baseline and 6 months.

Drinking risk reports for physicians about patients to guide drinking discussion, handed to physician before every scheduled visit. Telephone behavioural counselling $3 x$ (at baseline, 3-months and 6 months)

\section{Control group:}

Usual PC, which could have included alcohol counselling

\section{5-method (stepped-care):}

Various steps conducted by general physician. Step 1: identification of problem drinking and brief advice; Step 2: Assessment + 30-min feedback; Step 3: 4 sessions based (15 min) on CBT and MET.

* Sessions can be combined with pharmacological treatment (acamprosate, disulfiram, nalmefene, or naltrexone)

* Referral to next step happened when patient score $>15$ points on the AUDIT Control group:

Specialist treatment. Same pharmacological treatment was offered as in the intervention. Various options of psychological treatment (4 to 12 sessions of $45 \mathrm{~min}$ )

\section{Stepped care interventions:}

Step 1: 40 min session of behavioural change counselling: Step 2: MET (max four 50 min sessions on weekly basis); Step 3: referral to specialist alcohol treatment.

*Referral to next step happened when patients still consumed alcohol at hazardous levels after 4 weeks Control group:

5-min structured brief intervention + short self-help booklet outlining consequences of excessive alcohol consumption

\section{Stepped-care interventions}

Step 1: 20 min session of behavioural change counselling; Step 2: MET (three $40 \mathrm{~min}$ sessions on weekly basis)

Step 3: referral to specialist alcohol treatment. * Referral to next step happened when patients still consumed alcohol at hazardous levels after 4 weeks Control group:

5-min structured brief intervention + short self-help booklet outlining consequences of 
Table 1 Study characteristics (Continued)

\begin{tabular}{lllll}
\hline Study, year & $\begin{array}{l}\text { Design, study } \\
\text { duration }\end{array}$ & $\begin{array}{l}\text { Setting (country; } \\
\text { type of health } \\
\text { care } \\
\text { professional) }\end{array}$ & $\begin{array}{l}\text { Participants (inclusion criteria + } \\
\text { recruitment details) }\end{array}$ & Intervention \\
& &
\end{tabular}

High intensity models of care

Oslin et al., $\quad$ RCT

2013 [24] 6.5 months
United States

VA primary care clinics

excessive alcohol consumption.

$\begin{array}{llll}\text { Watkins } & \text { RCT } & \text { United States } & \geq 18 \text { years, probable OAUD according to ASS } \\ \text { et al., } 2017 & 6 \text { months } & \text { Federally qualified } & \text { ST. } \\ \text { [25] } & & \text { health center } & (n=377) \\ \text { (SUMMIT- } & & \text { (primary care) } & \begin{array}{l}\text { Recruitment: in primary care (not seeking } \\ \text { trial) }\end{array} \\ & & \text { treatment for AUD) }\end{array}$

trial)

$\begin{array}{lll}\text { Upshur } & \text { RCT } & \text { United States } \\ \text { et al., 2015 } & 6 \text { months } & \text { Health care for } \\ \text { [26] } & & \text { the homeless } \\ \text { Project } & \text { clinic } \\ \text { RENEWAL } & \end{array}$

\author{
$\geq 18$ years women seeking primary care \\ services who screened positive for hazardous \\ drinking (AUDIT-C score $>4$ ) \\ $(n=82)$ \\ Recruitment: in primary care (not seeking \\ treatment for AUD)
}

$\begin{array}{lll}\text { Bradley } & \text { RCT } & \text { United States } \\ \text { et al., } 2018 & \text { (encouragement); } & \text { VA primary care } \\ \text { [27] } & \text { clinics }\end{array}$

(CHOICE-

trial)

$\geq 18$ years, DSM-IV criteria for current alcohol Alcohol care management:

dependence, and $>2$ SD/ day for 60 days prior Weekly 30 min visits with BHP (assess alcohol Recruitment: in primary care (not seeking treatment for AUD) + patient request (seeking treatment for AUD) use, encouraged treatment adherence, offered support and education, monitoring medical problems, education about pharmacotherapy). Promotion of evidence-based pharmacotherapy (naltrexone $50 \mathrm{mg}$ ), however use was not a requirement of participation.

As participants improved, the frequency of visits could be reduced to twice per month after the first 3 months.

\section{Control group:}

Standard specialty care at the VA specialty outpatient addiction program, based on the 12-step facilitation model, including assessments, outpatient detoxification, counselling, pharmacotherapy, psychotherapy, psychoeducational groups, outreach and referral, and acupuncture. Patients were to be expected to attend Alcoholics and Anonymous.

\section{Collaborative care:}

6 sessions brief psychotherapy treatment and/ or medication-assisted treatment.

On-site behavioural health care, integration of addiction expertise through clinical psychologist with motivational interviewing experience, first appointment with care coordinators, entry into registry to track treatment progress and to prompt care coordinators to reach out to patients with missed appointments.

\section{Control group:}

Usual PC; participants were told that the clinic provided OAUD treatment and given a number for appointment scheduling and list of community referrals.

\section{Chronic care model:}

First, participants would get a brief intervention from the PCP and referral to the Care manager (CM) for ongoing care. PCP would provide 4-6 appointments for ongoing care and encouragement of addiction medication.

The CM was asked to complete at least 15 phone or in-person follow-up sessions in the 6 months.

\section{Control group:}

Usual PC + access to the specialty care offered in the clinic (e.g. counselling, psychiatry, etc).

Age 21-75; heavy drinking ( $\geq 4$ SD/occasion for women; $\geq 5 \mathrm{SD}$ for men) at least twice per week or once per week if prior alcohol treatment $(n=304)$

Recruitment: in primary care (not seeking treatment for AUD)

\section{Alcohol care management:}

$1-2$ engagement visits (focus on life goals, feedback from baseline assessment, using MET/SDM). Repeated nurse visits (review patient self-monitoring and/or biomarker) + provide behavioural goal setting skills development for reducing drinking, AUD medications, withdrawal management, mutual help, and referral to specialty addictions treatment per patient preference.

Control group: 
Table 1 Study characteristics (Continued)

\begin{tabular}{lllll}
\hline Study, year & $\begin{array}{l}\text { Design, study } \\
\text { duration }\end{array}$ & $\begin{array}{l}\text { Setting (country; } \\
\text { type of health } \\
\text { care } \\
\text { professional) }\end{array}$ & $\begin{array}{l}\text { Participants (inclusion criteria + } \\
\text { recruitment details) }\end{array}$ & Intervention \\
& &
\end{tabular}

\begin{tabular}{|c|c|c|c|}
\hline $\begin{array}{l}\text { Saitz et al., } \\
2013 \text { [28] } \\
\text { (alcohol } \\
\text { subgroup) } \\
\text { (AHEAD- } \\
\text { trial) }\end{array}$ & $\begin{array}{l}\mathrm{RCT} \\
12 \text { months }\end{array}$ & $\begin{array}{l}\text { United States } \\
\text { Hospital based PC } \\
\text { clinic }\end{array}$ & $\begin{array}{l}\geq 18 \text { years, Alcohol dependence according to } \\
\text { CIDI-SF and heavy drinking in the } 30 \text { days ( } \geq 5 \\
\text { SD/occasion at least twice or } \geq 22 \text { drinks per } \\
\text { week in an average week; } \geq 4 \text { and } \geq 15 \text {, re- } \\
\text { spectively, for women) } \\
\text { ( } n=409 \text { ). } \\
\text { Recruitment: detoxification facility, referrals } \\
\text { from hospital and advertisements (treatment } \\
\text { seeking for AUD) }\end{array}$ \\
\hline
\end{tabular}

Usual PC (offered annual behavioural health screening, integrated mental health services, and access to specialty mental health and addictions clinics)

Willenbring RCT et al., 199924 months [29]
United States Outpatient clinicMinneapolis VA medical center (MVAMC)
Patients with current diagnosis of severe medical illness due to alcohol use (e.g. alcoholic liver disease, alcoholic pancreatitis, etc.), recent pathological drinking (past 6 months) $(n=105)$

Recruitment: referral by medical providers + patients were identified when presenting to acute treatment units (not seeking treatment for AUD)

\section{Chronic care management:}

Study clinic with multidisciplinary team located in PC. Two 90-min visits separated by 3-4 days receiving assessments by all 4 clinicians. Four sessions of MET, relapse prevention, pharmacotherapy was offered as appropriate, facilitated referrals to addiction specialty care, drop in care and $24 \mathrm{~h}$ pager access.

Control group:

$\mathrm{PC}+$ a list of addiction treatment resources. They were given a phone number to access 4 MET sessions.

\section{Integrated outpatient treatment:}

Primary care professionals are principal caregiver. First, patient receive 1-2 day inpatient evaluation by a multidisciplinary team (internist, psychiatrist, nurse practitioner, psychologist, social worker) who make a treatment plan. After which, they are seen monthly for assessment and feedback (e.g. biological indicators) and offer of a support group. Important facets of the care provided are: case management, aggressive follow-up, and family involvement.

Control group:

Standard specialty care: separate referrals for alcohol treatment and outpatient primary medical care.

Alcoholism counsellors/ mental health professionals are principal caregiver in the alcoholism treatment.

CARET comorbid alcohol risk evaluation tool, AUDIT alcohol use disorder identification test, CIDI-SF Composite International Diagnostic Interview-Short Form, ASSI ST Alcohol, smoking and substance involvement screening test, ICD-10 International Statistical Classification of Diseases (10th revision), DSM Diagnostic and Statistical Manual of Mental Disorders, OAUD Opioid and alcohol use disorders, GDO Good drinking outcome;

* Statistically significant $P<0.05$

study by Willenbring et al. only included participants with a current diagnosis of severe medical illness due to excessive alcohol use (e.g. alcoholic pancreatitis) [29]. Three studies had strict exclusion criteria regarding current substance abuse and dependence [21, 22, 24] other than alcohol (a maladaptive pattern of substance use, such as cannabis or amphetamines, leading to clinically significant impairment and distress) while others did not mention this exclusion criterion. Two studies specifically included patients with AUD and substance use disorder (SUD) [25, 28 . Watkins et al. reported that $94 \%$ of the sample had an AUD, of which $40 \%$ had both an opioid and alcohol use disorder (OAUD) [30]. Data for the AUD subgroup without comorbid opioid dependence was obtained from the authors upon request. The study by Upshur et al. specifically included homeless women with AUD, whilst most others excluded homeless people from their studies [26].

\section{Setting}

Two studies were conducted in the United Kingdom $[22,23]$, one study was set in Sweden [21] and the remaining eight trials in the United States. Most studies were conducted in community primary care settings [19-23] and there were three studies set in VA primary care clinics [24, 27, 29]. Other locations included a hospital-based primary care clinic [28], a health centre for the homeless [26] and a federally qualified health centre [25].

\section{Study-design}

Two studies were cluster-randomised controlled trials $[20,26]$ and one study was labelled a randomised encouragement trial that offered services to patients but did not require that they accept [27]. None of the studies blinded participants or physicians. Six studies included 
blinded assessment of the outcomes (researchers were unaware of the patients' group assignment) $[19,20,22$, $24,25,27]$, however, alcohol consumption was often obtained by self-report (e.g. standard drinks (SD) of alcohol per week).

\section{Intervention}

The models of care in each of the studies differed significantly with regards to the duration, the setting, health professionals engaged and access to types of treatment. As a result, following data extraction, we decided to divide the models of care into lower intensity models and higher intensity models whereby the components for each of these are depicted in detail in Table 2.

\section{Lower intensity models}

The studies by Moore et al. [19] and Ettner et al. [20] evaluated a multi-faceted model with personalised patient reports, educational booklets and a drinking diary to educate patients about their drinking habits. The primary care physician would also receive a drinking report prior to every scheduled appointment to stimulate discussion about alcohol consumption. Subsequently, patients would receive 3 telephone behavioural counselling sessions. These two studies differed with regards to the timing of these counselling sessions (frontloading versus more spread out, respectively). The health professionals included a primary care physician and health educators.

The studies by Wallhed-Finn et al. [21], Drummond et al. [22] and Coulton et al. [23] evaluated a variation of a stepped-care model. They all started with a standard brief intervention $(5-10 \mathrm{~min})$. The intensity of the treatment increased when patients continued to drink at hazardous levels. Treatment included feedback, behavioural counselling (based on cognitive behavioural therapy (CBT) and/or motivational enhancement therapy (MET). Referral to specialty care would be followed if necessary. The model evaluated by Wallhed-Finn et al. [21] was unique in that it provided psychosocial therapy adapted to the context and time constraints of primary care with the option for any pharmacological treatment.

\section{Higher intensity models (longitudinal care models)}

Six of the included studies [24-29] assessed the effectiveness of models of care that were based on elements of the collaborative care/ chronic care model (CCM) [31, 32]. The six studies offered high intensity intervention with psychosocial support (MET and/or CBT) and pharmacological treatment for AUD. They all integrated addiction expertise and behavioural counselling support and assured good communication between primary care physicians and other health professionals using the electronic medical system (EMR). Often a case manager kept track of treatment and attendance, assuring active follow-up. To increase treatment engagement, CCM concepts such as shared-decision making and selfmanagement support were incorporated in these studies. Shared decision making directed the duration, length, type and intensity of the treatment. Self-management support was usually provided by biomarker testing feedback and routine assessment. Two out of six studies utilised specialty addiction treatment as the comparator. The remaining studies compared the care model against usual primary care with access to specialty addiction treatment resources.

\section{Control groups}

Control groups are described in detail in Table 1. These included usual primary care plus possible addition of alcohol counselling [20], an education booklet [19], $5 \mathrm{~min}$ structured brief intervention with self-help booklet [22, 23], provision of a number for outpatient treatment [25, 28], specialty counselling or psychiatry [26], annual behavioural health screening and integrated mental health services [27]. Addiction specialty treatment was the comparator model of care in three studies but may have been provided separately $[21,24,29]$.

\section{Quality appraisal}

Overall, the quality of the studies was mixed with most trials having a moderate risk of bias for both engagement and drinking outcome measures (see Table 3). More specifically, the majority of studies had low risk of bias arising from the randomisation process except for some risk of bias regarding cluster randomisation with Ettner et al. [20] and Upshur et al. 2015. With regards to bias due to deviations from the intended intervention in terms of assignment to intervention, the majority of studies had low risk of bias although our appraisal yielded some-high bias for Oslin et al. [24] and high bias for the Willenbring et al. [29]. All the studies were judged to have low risk of bias in terms of adhering to the intervention. Bias with regards to missing outcome data was observed in several studies including Drummond et al. [22], Watkins et al. [25], Willenbring et al. [29] and Upshur et al. [26]. Bias with regards to measurement of outcome was observed to some degree in all the studies except for Ettner et al. [20]. Half of the studies were judged to have some risk of bias regarding selection of reported results. Funding from the pharmaceutical industry was not apparent in 10 of the studies. In one of the studies, Watkins et al. [25], Alkermes provided long-acting injectable naltrexone at no charge to patients. None of the studies were blinded and all studies used self-reported measures for alcohol consumption. 
Table 2 Components of model of care

\begin{tabular}{|c|c|c|c|c|c|c|c|c|c|c|c|}
\hline & $\begin{array}{l}\text { Moore } \\
2010 \\
{[19]}\end{array}$ & $\begin{array}{l}\text { Ettner } \\
2014 \\
{[20]}\end{array}$ & $\begin{array}{l}\text { Wallhed- } \\
\text { Finn } 2018 \\
\text { [21] }\end{array}$ & $\begin{array}{l}\text { Drummond } \\
2009[22]\end{array}$ & $\begin{array}{l}\text { Coulton } \\
2017[23]\end{array}$ & $\begin{array}{l}\text { Oslin } \\
2013 \\
{[24]}\end{array}$ & $\begin{array}{l}\text { Watkins } \\
2017[25]\end{array}$ & $\begin{array}{l}\text { Upshur } \\
2015[26]\end{array}$ & $\begin{array}{l}\text { Bradley } \\
2018[27]\end{array}$ & $\begin{array}{l}\text { Saitz } \\
2013 \text { [28] }\end{array}$ & $\begin{array}{l}\text { Willenbring } \\
1999 \text { [29] }\end{array}$ \\
\hline & \multicolumn{5}{|c|}{ Lower intensity models } & \multicolumn{6}{|c|}{ Higher intensity models (longitudinal care) } \\
\hline \multicolumn{12}{|l|}{ Identification } \\
\hline Screening & $x$ & $x$ & $x$ & $x$ & $x$ & $x$ & $x$ & $x$ & $x$ & $x$ & $x$ \\
\hline (E) MR alterations & $x$ & $x$ & & & & & $x$ & $x$ & $x$ & $x$ & \\
\hline \multicolumn{12}{|c|}{ Increasing patient engagement } \\
\hline $\begin{array}{l}\text { Follow-up } \\
\text { (active) }\end{array}$ & & & & & & & $x$ & & $x$ & $x$ & $x$ \\
\hline $\begin{array}{l}\text { Shared-decision } \\
\text { making }\end{array}$ & & & $x$ & & & & $x$ & $x$ & $x$ & $x$ & \\
\hline $\begin{array}{l}\text { Goal setting } \\
\text { (flexibility) }\end{array}$ & & & $x$ & & & $x$ & & $x$ & $x$ & & $x$ \\
\hline $\begin{array}{l}\text { Self-management } \\
\text { support }\end{array}$ & & & & & & $x$ & $x$ & $x$ & $x$ & $x$ & \\
\hline $\begin{array}{l}\text { Patient education } \\
\text { (material) }\end{array}$ & $x$ & $x$ & & & & $x$ & & $x$ & $x$ & & \\
\hline $\begin{array}{l}\text { Biomarker } \\
\text { feedback }\end{array}$ & & & & & & & & & $x$ & $x$ & $x$ \\
\hline $\begin{array}{l}\text { Support system } \\
\text { involvement }\end{array}$ & & & & & & & & & & & $x$ \\
\hline \multicolumn{12}{|c|}{ Education health professionals } \\
\hline $\begin{array}{l}\text { Training of staff } \\
(>1 \mathrm{~h})\end{array}$ & & & $x$ & $x$ & $x$ & $x$ & $x$ & $x$ & $x$ & $x$ & \\
\hline $\begin{array}{l}\text { Feedback/ } \\
\text { supervision }\end{array}$ & & & & & $x$ & $x$ & $x$ & $x$ & $x$ & & \\
\hline $\begin{array}{l}\text { Specialist/ expert } \\
\text { consultations }\end{array}$ & & & & & $x$ & & $x$ & $x$ & $x$ & $x$ & $x$ \\
\hline \multicolumn{12}{|l|}{ Staff } \\
\hline $\begin{array}{l}\text { Primary care } \\
\text { staff** }\end{array}$ & $x$ & $x$ & $x$ & $x$ & $x$ & $x$ & $x$ & $x$ & $x$ & $X^{*}$ & $x$ \\
\hline $\begin{array}{l}\text { Psychologist/ } \\
\text { alcohol therapist }\end{array}$ & & & & $x$ & $x$ & $x$ & $x$ & + & & $x$ & \\
\hline Medical specialist & & & & & & & $x$ & + & & $x$ & $x$ \\
\hline $\begin{array}{l}\text { Case manager/ } \\
\text { care coordinator }\end{array}$ & & & & & & & $x$ & $x$ & $x$ & $x$ & $x$ \\
\hline \multicolumn{12}{|l|}{ Treatment } \\
\hline $\begin{array}{l}\text { (Brief) } \\
\text { psychosocial } \\
\text { therapy }\end{array}$ & $x$ & $x$ & $x$ & $x$ & $x$ & $x$ & $x$ & $x$ & $x$ & $x$ & $x$ \\
\hline $\begin{array}{l}\text { AUD } \\
\text { pharmacotherapy }\end{array}$ & & & $x$ & & & $x$ & $x$ & $x$ & $x$ & $x$ & \\
\hline Self-help groups & & & & & & & $x$ & $x$ & $x$ & $x$ & $x$ \\
\hline \multicolumn{12}{|c|}{ Linkage to specialty services } \\
\hline $\begin{array}{l}\text { Referral to } \\
\text { specialty care }\end{array}$ & & & & $x$ & $x$ & & $x$ & $x$ & $x$ & $x$ & $x$ \\
\hline $\begin{array}{l}\text { Social/ } \\
\text { community } \\
\text { services }\end{array}$ & & & & & & & $x$ & $x$ & & $x$ & $x$ \\
\hline \multicolumn{12}{|c|}{ Duration of intervention (treatment) } \\
\hline $\begin{array}{l}\text { Up to three } \\
\text { months }\end{array}$ & $x$ & & $x$ & $x$ & $x$ & & & & & & \\
\hline Three to six & & & & & & $x$ & $x$ & $x$ & & & \\
\hline
\end{tabular}


Table 2 Components of model of care (Continued)

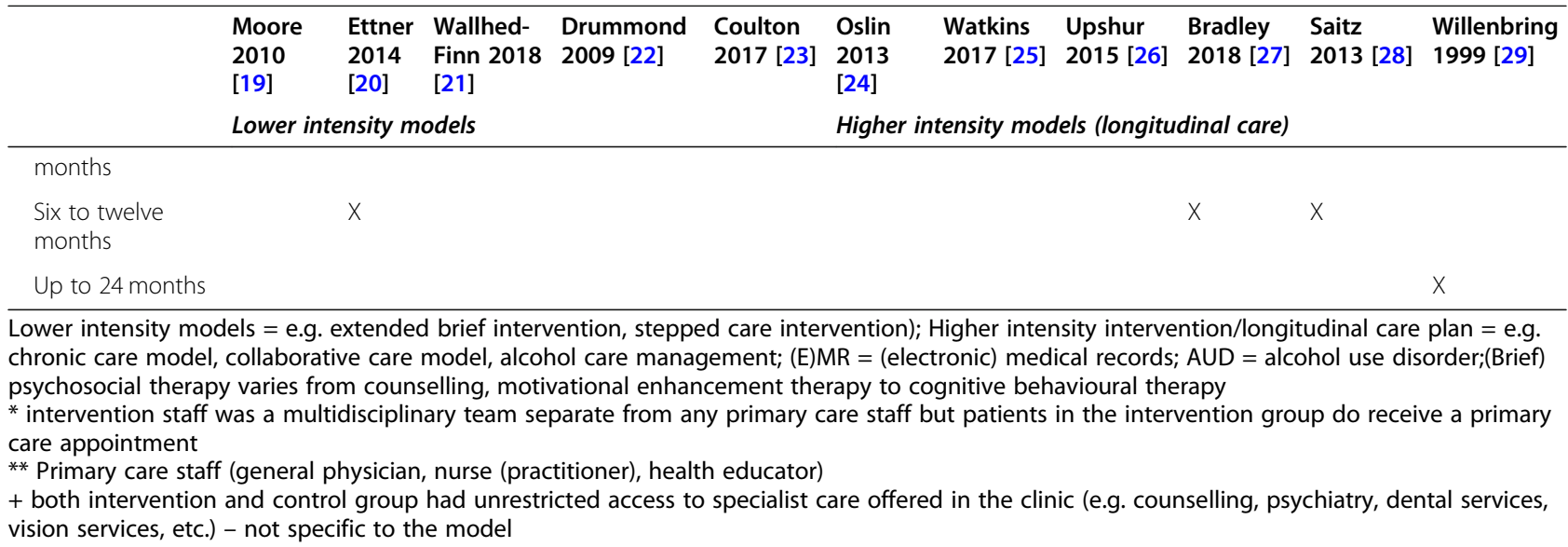

\section{Effectiveness}

We aimed to evaluate effectiveness of models of care in primary care-settings in increasing treatment engagement and reducing alcohol consumption via meta- analytic synthesis. However, due to the small number of studies, high heterogeneity between studies, and due to large variations in outcome measures, meta-analysis was not feasible. We thus illustrated patterns using tables.

Table 3 Bias assessment of engagement outcome measures (first) and clinical/drinking outcome measures (second)

\begin{tabular}{|c|c|c|c|c|c|c|c|c|}
\hline Reference & $\begin{array}{l}\text { Domain } 1 \text {; bias } \\
\text { arising from } \\
\text { the } \\
\text { randomization } \\
\text { process }\end{array}$ & $\begin{array}{l}\text { Domain } 1 \mathrm{~b} ; \text { bias } \\
\text { arising from the } \\
\text { randomization } \\
\text { process (cluster- } \\
\text { randomized } \\
\text { trials) }\end{array}$ & $\begin{array}{l}\text { Domain 2; bias } \\
\text { due to deviations } \\
\text { from the intended } \\
\text { intervention } \\
\text { (assignment to } \\
\text { intervention) }\end{array}$ & $\begin{array}{l}\text { Domain 2; bias } \\
\text { due to deviations } \\
\text { from the intended } \\
\text { interventions } \\
\text { (adhering to } \\
\text { intervention) }\end{array}$ & $\begin{array}{l}\text { Domain } \\
3 ; \text { bias } \\
\text { due to } \\
\text { missing } \\
\text { outcome } \\
\text { data }\end{array}$ & $\begin{array}{l}\text { Domain 4; } \\
\text { bias in } \\
\text { measurement } \\
\text { of the } \\
\text { outcome }\end{array}$ & $\begin{array}{l}\text { Domain } \\
5 ; \text { bias in } \\
\text { selection } \\
\text { of the } \\
\text { reported } \\
\text { results }\end{array}$ & $\begin{array}{l}\text { Overall } \\
\text { risk of } \\
\text { bias } \\
\text { judgement }\end{array}$ \\
\hline $\begin{array}{l}\text { Bradley } \\
\text { et al., } 2018\end{array}$ & $\begin{array}{l}\text { Low risk } \\
\text { Low risk }\end{array}$ & $\mathrm{NA}$ & $\begin{array}{l}\text { Low risk } \\
\text { Low risk }\end{array}$ & $\begin{array}{l}\text { Low risk } \\
\text { Low risk }\end{array}$ & $\begin{array}{l}\text { Low risk } \\
\text { Low risk }\end{array}$ & $\begin{array}{l}\text { Low risk } \\
\text { Some risk }\end{array}$ & $\begin{array}{l}\text { Some risk } \\
\text { Some risk }\end{array}$ & $\begin{array}{l}\text { Some risk } \\
\text { Some risk }\end{array}$ \\
\hline $\begin{array}{l}\text { Coulton } \\
\text { et al., } 2017 \\
{[23]}\end{array}$ & $\begin{array}{l}\text { NA } \\
\text { Low risk }\end{array}$ & NA & $\begin{array}{l}\text { NA } \\
\text { Low risk }\end{array}$ & $\begin{array}{l}\text { NA } \\
\text { Low risk }\end{array}$ & $\begin{array}{l}\text { NA } \\
\text { Low risk }\end{array}$ & $\begin{array}{l}\text { NA } \\
\text { Some risk }\end{array}$ & $\begin{array}{l}\text { NA } \\
\text { Low risk }\end{array}$ & $\begin{array}{l}\text { NA } \\
\text { Low risk }\end{array}$ \\
\hline $\begin{array}{l}\text { Drummond } \\
\text { et al., } 2009 \\
\text { [22] }\end{array}$ & $\begin{array}{l}\text { NA } \\
\text { Low risk }\end{array}$ & NA & $\begin{array}{l}\text { NA } \\
\text { Low risk }\end{array}$ & $\begin{array}{l}\text { NA } \\
\text { Low risk }\end{array}$ & $\begin{array}{l}\text { NA } \\
\text { High risk }\end{array}$ & $\begin{array}{l}\text { NA } \\
\text { Some risk }\end{array}$ & $\begin{array}{l}\text { NA } \\
\text { Some risk }\end{array}$ & $\begin{array}{l}\text { NA } \\
\text { High risk }\end{array}$ \\
\hline $\begin{array}{l}\text { Ettner et al., } \\
2014 \text { [20] }\end{array}$ & $\begin{array}{l}\text { Low risk } \\
\text { Low risk }\end{array}$ & $\begin{array}{l}\text { Some risk } \\
\text { Some risk }\end{array}$ & $\begin{array}{l}\text { Low risk } \\
\text { Low risk }\end{array}$ & $\begin{array}{l}\text { NA } \\
\text { NA }\end{array}$ & $\begin{array}{l}\text { Low risk } \\
\text { Low risk }\end{array}$ & $\begin{array}{l}\text { Low risk } \\
\text { Low risk }\end{array}$ & $\begin{array}{l}\text { Low risk } \\
\text { Low risk }\end{array}$ & $\begin{array}{l}\text { Some risk } \\
\text { Some risk }\end{array}$ \\
\hline $\begin{array}{l}\text { Moore et al., } \\
2010 \text { [19] }\end{array}$ & $\begin{array}{l}\text { NA } \\
\text { Low risk }\end{array}$ & NA & $\begin{array}{l}\text { NA } \\
\text { Low risk }\end{array}$ & $\begin{array}{l}\text { NA } \\
\text { Low risk }\end{array}$ & $\begin{array}{l}\text { NA } \\
\text { Low risk }\end{array}$ & $\begin{array}{l}\text { NA } \\
\text { Some risk }\end{array}$ & $\begin{array}{l}\text { NA } \\
\text { Some risk }\end{array}$ & $\begin{array}{l}\text { NA } \\
\text { Some risk }\end{array}$ \\
\hline $\begin{array}{l}\text { Oslin et al., } \\
2013 \text { [24] }\end{array}$ & $\begin{array}{l}\text { Low risk } \\
\text { Low risk }\end{array}$ & NA & $\begin{array}{l}\text { Some risk } \\
\text { High risk }\end{array}$ & $\begin{array}{l}\text { Low risk } \\
\text { Low risk }\end{array}$ & $\begin{array}{l}\text { Low risk } \\
\text { Low risk }\end{array}$ & $\begin{array}{l}\text { High risk } \\
\text { Low risk }\end{array}$ & $\begin{array}{l}\text { Some risk } \\
\text { Some risk }\end{array}$ & $\begin{array}{l}\text { High risk } \\
\text { High risk }\end{array}$ \\
\hline $\begin{array}{l}\text { Saitz et al., } \\
2013 \text { [28] }\end{array}$ & $\begin{array}{l}\text { Low risk } \\
\text { Low risk }\end{array}$ & NA & $\begin{array}{l}\text { Low risk } \\
\text { Low risk }\end{array}$ & $\begin{array}{l}\text { Low risk } \\
\text { Low risk }\end{array}$ & $\begin{array}{l}\text { Low risk } \\
\text { Low risk }\end{array}$ & $\begin{array}{l}\text { Some risk } \\
\text { Some risk }\end{array}$ & $\begin{array}{l}\text { Some risk } \\
\text { Some risk }\end{array}$ & $\begin{array}{l}\text { Some risk } \\
\text { Some risk }\end{array}$ \\
\hline $\begin{array}{l}\text { Watkins } \\
\text { et al., } 2017 \\
\text { [25] }\end{array}$ & $\begin{array}{l}\text { Low risk } \\
\text { Low risk }\end{array}$ & NA & $\begin{array}{l}\text { Low risk } \\
\text { Low risk }\end{array}$ & $\begin{array}{l}\text { Low risk } \\
\text { Low risk }\end{array}$ & $\begin{array}{l}\text { Low risk } \\
\text { Some risk }\end{array}$ & $\begin{array}{l}\text { Low risk } \\
\text { Some risk }\end{array}$ & $\begin{array}{l}\text { Low risk } \\
\text { Low risk }\end{array}$ & $\begin{array}{l}\text { Low risk } \\
\text { Some risk }\end{array}$ \\
\hline $\begin{array}{l}\text { Willenbring } \\
\text { et al., } 1999 \\
\text { [29] }\end{array}$ & $\begin{array}{l}\text { Low risk } \\
\text { Low risk }\end{array}$ & NA & $\begin{array}{l}\text { High risk } \\
\text { High risk }\end{array}$ & $\begin{array}{l}\text { Low risk } \\
\text { Low risk }\end{array}$ & $\begin{array}{l}\text { Some risk } \\
\text { Some risk }\end{array}$ & $\begin{array}{l}\text { Low risk } \\
\text { Some risk }\end{array}$ & $\begin{array}{l}\text { Some risk } \\
\text { Some risk }\end{array}$ & $\begin{array}{l}\text { High risk } \\
\text { High risk }\end{array}$ \\
\hline $\begin{array}{l}\text { Wallhed } \\
\text { finn et al., } \\
2018 \text { [21] }\end{array}$ & $\begin{array}{l}\text { Low risk } \\
\text { Low risk }\end{array}$ & NA & $\begin{array}{l}\text { Low risk } \\
\text { Low risk }\end{array}$ & $\begin{array}{l}\text { Low risk } \\
\text { Low risk }\end{array}$ & $\begin{array}{l}\text { Low risk } \\
\text { Low risk }\end{array}$ & $\begin{array}{l}\text { Low risk } \\
\text { Some risk }\end{array}$ & $\begin{array}{l}\text { Low risk } \\
\text { Low risk }\end{array}$ & $\begin{array}{l}\text { Low risk } \\
\text { Low risk }\end{array}$ \\
\hline $\begin{array}{l}\text { Upshur } \\
\text { et al., } 2015 \\
\text { [26] }\end{array}$ & $\begin{array}{l}\text { Low risk } \\
\text { Low risk }\end{array}$ & $\begin{array}{l}\text { Some risk } \\
\text { Some risk }\end{array}$ & $\begin{array}{l}\text { Some risk } \\
\text { Some risk }\end{array}$ & $\begin{array}{l}\mathrm{NA} \\
\mathrm{NA}\end{array}$ & $\begin{array}{l}\text { Some risk } \\
\text { Low risk }\end{array}$ & $\begin{array}{l}\text { Some risk } \\
\text { Low risk }\end{array}$ & $\begin{array}{l}\text { Some risk } \\
\text { Some risk }\end{array}$ & $\begin{array}{l}\text { High risk } \\
\text { High risk }\end{array}$ \\
\hline
\end{tabular}


Table 4 Engagement measures

\section{Reference, study duration}

Moore et al. 2010 [19]

12 months

Ettner et al. 2014 [20]

12 months

Wallhed-Finn et al. 2018 [21]

6 months

Drummond et al. 2009 [22]

6 months

Coulton et al. 2017 [23]

12 months

Oslin et al. 2013 [24]

6.5 months

Watkins et al. 2017 [25]

SUMMIT trial

(Data of AUD subgroup without

comorbid opioid dependence)

6 months

Upshur et al. 2015 [26]

Project RENEWAL

6 months

Bradley et al. 2018 [27]

$\mathrm{CHOlCE}$ tria

12 months

Saitz et al. 2013 [28]

AHEAD trial

(Data of AUD subgroup with/ without

SUD)

12 months

Willenbring et al. 1999 [29]

24 months

\section{Outcome measures}

NA

-Alcohol discussion with PC physician, \%

-Number of visits, mean

-Duration of treatment, $\min$

-AUD pharmacotherapy, \%

NA

NA

-Mean number of visits (SD)

-Proportion of patients with at least two addiction treatment visits

-Patients treated with naltrexone, \%

-Patients received any evidence-based treatment, \%

-Patients received any brief treatment, \%

-Patients received any medication assisted treatment, \%

-HEDIS initiation, \%

-HEDIS engagement, \%

-Number of visits, mean (6 mo)

-Meet criteria for spending time in drug/alcohol treatment, \% (3 \&6 mo)

-Talking about substance abuse with counsellor, \% (3 \& 6 mo)

-Attending AA meetings, \% (3 \& 6 mo)

-Patients visiting mental health provider, \%, (3 \& 6 mo)

-Total contacts with any substance use service, \% (3 \& 6 mo)

-AUD medication use, \% (3\&12 mo)

-AUD medication use > 30 days, \%, (3 \&12 mo)

-VA addictions treatment, \%, (3\&12 mo)

-AA involvement, \% (12 mo)

-Any alcohol-related care, \% (3\&12 mo)

-Any mutual help meeting attendance, \%

-Any addiction treatment, \%

-Any inpatient addiction treatment, \%

-Any addiction medication, \%

-VA hospital days over prior 2 year, psychiatric and alcohol treatment, mean

\section{Results (95\% Confidence interval)}

$\mathrm{I}=23 \%$ vs C $=13 \%$ **

$\mathrm{I}=2.9$ vs $\mathrm{C}=4.7^{* * *}$

$\mathrm{I}=74$ vs $\mathrm{C}=187^{* * *}$

NS

NS

OR $6.97(4.04,12.05)^{* * *}$

$\mathrm{I}=65.9$ vs $\mathrm{C}=11.5^{* * *}$

I $=39.4$ vs $C=15.2 ;$ OR 5.09 (2.33-

$11.14)^{* * *}$

$\mathrm{I}=37.5$ vs $\mathrm{C}=10.10 ;$ OR 7.70 (3.33$18.32)^{* * *}$

NS

$I=32.69$ vs $C=9.09 ;$ OR $6.16(2.56$ $14.85)^{* * *}$

I $=14.42$ vs $C=4.04 ;$ OR $6.56(1.78$ $24.15)^{*}$

$\mathrm{I}=12.1$ vs $\mathrm{C}=6.2^{* *}$

NS, NS

$3 \mathrm{mo}: \mathrm{I}=67.6$ vs $\mathrm{C}=30.6^{* *}$

6 mo: NS

NS, NS

NS, NS

$3 \mathrm{mo}: \mathrm{I}=75.7$ vs $\mathrm{C}=44.4^{*}$ $6 \mathrm{mo}: \mathrm{I}=75$ vs $\mathrm{C}=47.2^{* *}$

$3 \mathrm{mo}: \mathrm{I}=14$ vs $\mathrm{C}=4.6^{* *}$

$12 \mathrm{mo}: \mathrm{I}=32$ vs $\mathrm{C}=8.4^{* * *}$

3 mo: $1=9.3$ vs $C=26^{* *}$

$12 \mathrm{mo}: \mathrm{I}=26.0$ vs $\mathrm{C}=7.1^{* * *}$

NS, NS

NS

$3 \mathrm{mo}: \mathrm{I}=18$ vs $\mathrm{C}=8.4^{* *}$

$12 \mathrm{mo}: \mathrm{I}=42.0$ vs $\mathrm{C}=26.0^{* *}$

NS

I $=43$ vs $C=42$; OR $1.36(1.01-1.84)^{*}$

NS

$I=16$ vs $C=10 ;$ OR $2.12(1.29-3.48)^{* *}$

NS

$\mathrm{I}=42.2$ vs $\mathrm{C}=17.4^{* *}$

Mo months, VA Veterans Affairs, NS not significant; ${ }^{*} p<0.05,{ }^{* *} P<0.01 ;{ }^{* *} P<0.001$. Shading: indicates addiction specialty care as control group 


\section{Treatment engagement}

We tabulated treatment engagement outcomes with significant results (Table 4). There was a high heterogeneity between studies in outcome measures for treatment engagement. The uptake of AUD medication was reported in 5 out of 6 studies that offered AUD medication. Three studies reported a significantly higher uptake of AUD medication in the intervention group.

\section{Reduction of alcohol consumption}

Clinical outcomes relating to alcohol consumption are presented in Table 5. Similarly, there was a high heterogeneity between the clinical outcome measures. Significant reductions in alcohol consumption in patients treated in primary care settings relative to comparison groups were reported in almost half of the studies (two out of five lower intensity models; three out six higher intensity models). The studies by Bradley et al., Saitz et al. and Upshur et al. reported alcohol reduction in both the intervention and control group.

Heavy drinks per drinking day (HDD) in the past month at follow-up was reported by four studies, three of which were considered higher intensity models of care. The definition of HDD most commonly used was: women $\geq 4$ SD and men $\geq 5$ SD per day of approximately $14 \mathrm{~g}$ of ethanol per SD. However, the study by WallhedFinn et al. considered HDD as: women $>3$ SD and men $>4 \mathrm{SD}$ of $12 \mathrm{~g}$ per day. Only the study by Oslin et al. reported a benefit of intervention compared to control for this outcome measure.

\section{Discussion}

In the current review we examined the evidence base supporting treatment of AUD in primary care settings, providing an overview of the models of care. The models of care were generally aligned to either lower intensity models of care such as extended brief intervention and stepped care or higher intensity care models that were often based on the principles of the collaborative care/ chronic care model (CCM) [10, 31-34]. We were unable to extract sufficient data to conduct a meta-analysis due to variability in study measures and outcome data reporting. Nonetheless, we observed that the majority of care models improved treatment engagement of AUD patients, although the lower intensity models often did not report engagement outcomes. Significant reductions in alcohol consumption in patients treated in primary care settings relative to comparison groups were reported in less than half of the studies (two out of five lower intensity models; three out six higher intensity models) with more than half (seven out of eleven studies) reporting significant reductions in any alcohol outcomes (e.g. heavy drinking or alcohol-related problems).
Several methodological differences may explain mixed findings with regards to alcohol outcomes, such as inconsistent treatment compliance, shorter treatment duration and inadequate training of staff and/or lack of fidelity measures for psychosocial techniques. In addition, negative studies all reported similar reductions of alcohol consumption in both the intervention and control group, which may indicate issues with study design regarding comparison groups. None of the studies were blinded and, for example, in the study by Upshur et al. feedback of screening was provided to all participants which may have served as a brief intervention, prompting physicians to commence AUD treatment [26] or for mild AUD patients [35] to reduce consumption [14, 36].

Regarding higher intensity models of care, there were three studies that reported significant reductions in alcohol consumption (reduced HDD or increased abstinence), relative to control $[24,25,29,30]$. These studies did not include participants with co-morbid SUD, and for those that did, the beneficial results were restricted to the AUD participants only [24, 25, $29,30]$. In comparison, the higher intensity trials with null results included individuals with co-morbid SUD [26-28]. It is thus possible that the primary care model may be somewhat limited for patients with more complex needs, although studies with CCM for other conditions have reported effectiveness, even in patients with high social needs and co-morbidity [37]. Higher intensity models also often included patients with higher drinking levels and engagement of multiple healthcare professionals (e.g. psychologists, medical specialists, case managers). While the current systematic review demonstrates that provision of AUD treatment can be implemented in primary care, there is a gap in the evidence base regarding our capacity to define which patients are suitable for AUD treatment in primary care and which interventions are effective. Finally, the issue of feasibility in terms of time constraints and resources, particularly for complex patients, should not be underestimated as a barrier to widespread adoption of AUD treatment in primary care.

It is worth noting that our findings suggest pharmacotherapy can be simply and safely provided in the primary care setting. Which may lead to increased uptake and engagement with AUD treatment. There is thus potential for wide-spread benefit should primary care physicians adopt the responsibility for recognition, screening and prescribing. The provision of education regarding pharmacological treatment options could overcome some previously noted barriers such as lack of knowledge about the available treatment possibilities and misconceptions about medication efficacy [38-40]. 
Table 5 Clinical outcomes / alcohol consumption measures

\begin{tabular}{|c|c|c|}
\hline Reference & Outcome measures & Results (95\% Confidence Interval) \\
\hline \multirow[t]{3}{*}{$\begin{array}{l}\text { Moore et al. } 2010[19] \\
12 \text { months }\end{array}$} & -At-risk drinking, \% (3 \& 12 mo) & $\begin{array}{l}3 \mathrm{mo}: \mathrm{I}=49.6 \text { vs } \mathrm{C}=61.2 ; \text { OR } 0.41(0.22- \\
0.75)^{* *} \\
12 \mathrm{mo}: \mathrm{NS}\end{array}$ \\
\hline & -One or more HDD in past 7 days, $\%$ (3 \& 12 mo) & $\begin{array}{l}3 \mathrm{mo}: \mathrm{I}=10.3 \text { vs } \mathrm{C}=16.9 ; \text { OR } 0.46(0.22- \\
0.99)^{*} \\
12 \mathrm{mo}: \mathrm{NS}\end{array}$ \\
\hline & -Number of drinks in past 7 days, mean ( 3 \& 12 mo) & $\begin{array}{l}3 \mathrm{mo:} \text { I }=8.9 \text { vs } C=10.7 \text {; OR } 0.79(0.7- \\
0.9)^{* * *} \\
12 \mathrm{mo}: \mathrm{I}=9.39 \text { vs } C=10.70 \text {; OR } 0.87(0.76- \\
0.99)^{*}\end{array}$ \\
\hline \multirow[t]{2}{*}{$\begin{array}{l}\text { Ettner et al. } 2014 \text { [20] } \\
12 \text { months }\end{array}$} & -At-risk dinking, \% (6 \& $12 \mathrm{Mo})$ & $\begin{array}{l}6 \mathrm{mo}: \mathrm{I}=60 \text { vs } C=72^{* *} \\
12 \mathrm{mo}: \mathrm{I}=56 \text { vs } C=67^{* *}\end{array}$ \\
\hline & -Drinks per week, no, (6 \& 12 Mo) & $\begin{array}{l}6 \mathrm{mo}: \mathrm{I}=9.82 \text { vs } C=12.24^{* *} \\
12 \mathrm{mo}: \mathrm{I}=9.45 \text { vs } C=11.64^{* *}\end{array}$ \\
\hline \multirow{5}{*}{$\begin{array}{l}\text { Wallhed-Finn et al. } 2018 \text { [21] } \\
6 \text { months }\end{array}$} & -Weekly alcohol consumption, gr & NS \\
\hline & - Heavy drinking days per month & NS \\
\hline & -ICD-10 criteria dependence at follow up & NS \\
\hline & -SIP total score & NS \\
\hline & -Proportion patients drinking under recommended levels & NS \\
\hline \multirow{4}{*}{$\begin{array}{l}\text { Drummond et al. } 2009 \text { [22] } \\
6 \text { months }\end{array}$} & -Total number of drinks consumed in period & NS \\
\hline & -Drinks per drinking day & NS \\
\hline & -Percentage of days abstinent & NS \\
\hline & -Alcohol problems questionnaire & NS \\
\hline \multirow{3}{*}{$\begin{array}{l}\text { Coulton et al. } 2017 \text { [23] } \\
12 \text { months }\end{array}$} & -Average drinks per day, mean (6 \& 12 mo) & NS, NS \\
\hline & -AUDIT-C score, mean (6 \&12 mo) & NS, NS \\
\hline & -AUCIT-C score, positive \%, (6 \&12 mo) & NS, NS \\
\hline \multirow{4}{*}{$\begin{array}{l}\text { Oslin et al. } 2013 \text { [24] } \\
6.5 \text { months }\end{array}$} & -Presence/absence heavy drinking & NS \\
\hline & -Percent days heavy drinking ${ }^{a}$ & OR $2.16(1.27,3.66)^{*}$ \\
\hline & -Presence/ absence of any drinking & NS \\
\hline & $-S I P$ & NS \\
\hline \multirow{5}{*}{$\begin{array}{l}\text { Watkins et al. } 2017 \text { [25] } \\
\text { SUMMIT trial } \\
\text { (Participant data of AUD subgroup without } \\
\text { comorbid opioid dependence) } \\
6 \text { months }\end{array}$} & $\begin{array}{l}\text {-Abstinence from all opioids and any alcohol, past } 30 \text { days, } \\
\%\end{array}$ & $\mathrm{I}=25.32$ vs $C=15.71 ; \beta 0.21(0.07-0.35)^{*}$ \\
\hline & $\begin{array}{l}\text {-Abstinence from opioids, any alcohol, cocaine, } \\
\text { methamphetamines and marijuana, past } 30 \text { days, \% }\end{array}$ & $I=21.52$ vs $C=14.29 ; \beta 0.17(0.04-0.30)^{*}$ \\
\hline & -Heavy drinking, past 30 days, $\%$ & NS \\
\hline & -Abstinence from all opioids and no heavy drinking, \% & $I=44.29$ vs $C=36.51 ; \beta 0.26(0.10-0.42)^{* *}$ \\
\hline & -SIP score, alcohol \& drugs score, mean & NS \\
\hline \multirow[t]{4}{*}{$\begin{array}{l}\text { Upshur et al. } 2015 \text { [26] } \\
\text { Project RENEWAL } \\
6 \text { months }\end{array}$} & $\begin{array}{l}\text {-Reduction in of drinks per month (baseline to } 6 \text { months), } \\
\text { median }\end{array}$ & $\begin{array}{l}\mathrm{I}=185 \mathrm{SD} / \mathrm{month} \text { to } 12 \mathrm{SD} / \mathrm{month}^{* *} \\
\mathrm{C}=87.3 \mathrm{SD} / \mathrm{month} \text { to } 1.3 \mathrm{SD} / \mathrm{month}^{* *} \\
\text { difference between I and } \mathrm{C}=\mathrm{NS}\end{array}$ \\
\hline & -Nr drinks/month last 3 months, Median (SD) (3 \& 6 mo) & NS, NS \\
\hline & -Nr drinks last 3 months (3 \& 6 mo) & NS, NS \\
\hline & -Alcohol use consequences, mean (SD) (3 \& 6 mo) & NS, NS \\
\hline \multirow{5}{*}{$\begin{array}{l}\text { Bradley et al. } 2018[27] \\
\text { CHOICE trial } \\
12 \text { months }\end{array}$} & -Heavy drinking days, \% (3 \&12 mo) & NS, NS \\
\hline & -Patients with good drinking outcomes, \% (3 \& 12 mo) & NS, NS \\
\hline & -Patients with no heavy drinking days, \% (3 \&12 mo) & NS, NS \\
\hline & -Days abstinent, \% (3 \& 12 mo) & $\begin{array}{l}3 \mathrm{mo:}: \mathrm{I}=30 \text { vs } C=38^{*} \\
12 \mathrm{mo}: \mathrm{I}=35 \text { vs } \mathrm{C}=45^{*}\end{array}$ \\
\hline & -Patients abstinent, \% (3 \&12 mo) & NS, NS \\
\hline
\end{tabular}


Table 5 Clinical outcomes / alcohol consumption measures (Continued)

\begin{tabular}{|c|c|c|}
\hline Reference & Outcome measures & Results (95\% Confidence Interval) \\
\hline & -Patient drinking below weekly limits, $\%$ & NS, NS \\
\hline & -SIP score, mean & NS, NS \\
\hline \multirow{3}{*}{$\begin{array}{l}\text { Saitz et al. } 2013 \text { [28] } \\
\text { AHEAD trial } \\
\text { (Data of AUD subgroup with/ without SUD) } \\
12 \text { months }\end{array}$} & -Abstinence from heavy drinking, past 30 days, $\%$ & NS \\
\hline & -No. of heavy drinking days in past 30 days, mean & NS \\
\hline & -Alcohol-related problem score, mean & $I=10.4$ vs $C=13.1 ;$ OR $0.85(0.72-1.00)^{*}$ \\
\hline \multirow{5}{*}{$\begin{array}{l}\text { Willenbring et al. } 1999 \text { [29] } \\
24 \text { months }\end{array}$} & -Positive DSM-II-R criteria (0-9), No & NS \\
\hline & -Drinking days during last 30 days, mean & $I=3.7$ vs $C=7.0^{*}$ \\
\hline & -Drinks per drinking day, No & $I=1.8$ vs $C=3.0^{*}$ \\
\hline & -Days since last drink, mean & NS \\
\hline & -Abstinent, \% & $I=74$ vs $C=48^{*}$ \\
\hline
\end{tabular}

Mo months, NS not significant, OR Odds ratio, SD standard drink; ${ }^{*} p<0.05,{ }^{* *} P<0.01 ;{ }^{* * *} P<0.001 ;{ }^{a}$ Timing of measurements unknown. Shading: indicates addiction specialty care as control group

\section{Recommendations for primary care alcohol treatment research \\ Alcohol outcome measures}

Future alcohol treatment research in primary care settings will require more consistent measures of relevant alcohol-related outcomes. Both 1) sustained abstinence and also 2) no heavy drinking days are the two potential AUD treatment outcome measures recommended by various bodies [41, 42]. Sustained abstinence is arguably a 'gold standard' outcome but is infrequently achieved and reliance on this measure may underestimate treatment effects. Reductions in the World Health Organization (WHO) risk drinking levels [43] have recently been proposed as an alternative primary outcome for all alcohol clinical trials [44] and these endpoints are suitable for primary care alcohol treatment research. Findings among both AUD treatment seekers and the general drinking population show that reductions in WHO risk drinking levels are associated with improvements in physical and mental health such as liver disease, depression and anxiety [45-47]. We suggest consistent reporting of WHO risk levels will facilitate cross comparison of outcomes and also provision of clinically significant measures of improvement as outlined above.

The use of objective markers of alcohol use to corroborate self-report may also serve to improve consistency and quality of alcohol treatment research in primary care settings. One example is phosphatidylethanol (PEth) which is the new gold standard for reliable laboratory corroboration of alcohol consumption [48, 49]. While likely to be less accessible in primary care settings at the current time this may change in future years. Liver enzymes particularly $\gamma$-glutamyltransferase (GGT) are highly relevant to harms of AUD and also serve as an objective marker of recent consumption. These tests are readily available in primary care settings and are generally cheap and acceptable to most patients. Falling levels of aspartate transaminase (AST), alanine aminotransferase (ALT), and GGT are strongly correlated with alcohol consumption and associated with better health outcomes [50].

\section{Predictors of treatment engagement and response}

Patient characteristics such as alcohol severity and readiness to change may potentially predict suitability for alcohol treatment in a primary care setting. The Alcohol Use Disorders identification Test (AUDIT)-C, which is first 3 questions of the 10-item AUDIT, assesses alcohol consumption patterns in the past year and has been validated as a brief alcohol-screening test [51] and widely recommended for use in primary care. While consumption obtained via the AUDIT-C is not always entirely accurate, with potential for underestimation of actual consumption [52], increasing scores are associated with increasing severity of alcohol-related problems in the past 12 months [53].

Patients with higher readiness to change scores are associated with improved treatment engagement and alcohol use outcomes [54]. Thus, the potential for varying degrees of treatment seeking and ambivalence about treatment should be measured given that patients in primary care may not be interested in receiving AUD treatment. There are several validated readiness to change measures such as the Readiness to Change Questionnaire [55] and the Stages of Change Readiness and Treatment Eagerness Scale [56]. However, although relatively brief, these require dedicated data collection and consequently researcher input. Brief assessments and algorithms of readiness to change suitable for primary care also exist with face validity and potentially good concurrent validity when compared with the longer Readiness to Change Questionnaire $[57,58]$. 


\section{Method of data collection}

The emerging secondary use of electronic medical records (EMRs) for research purposes is occurring throughout the world [59]. As EMRs become more widely adopted in primary health care, research in these settings will be improved. Information from primary care EMRs can be used to evaluate the treatment outcome and uptake and also treatment fidelity, which would be particularly useful for evaluating psychosocial interventions (to the extent that these are recorded). EMRs can also be used to evaluate implementation facilitators and barriers and potentially assist in recruitment by earlier screening for alcohol problems [60]. Data linkage with repositories of primary care clinical data will significantly improve our capacity to evaluate treatment in these settings [61]. While these systems may already be utilised consistently in some countries they are not in many regions. For example, in Australia, there are multiple EMR systems that limit use of primary health care data for research and for data linkage between health care settings [59].

\section{Limitations}

One of the main limitations is the use of varied outcome measures across studies which makes comparison of study findings difficult. In addition, it is important to note that the synthesis of non-inferiority trials, comparing primary care management versus specialty care management, may be complicated by potential varying degrees of treatment seeking in the patients involved and ambivalence about need for treatment. The majority of AUD treatment trials in addiction specialty care settings involve treatment seeking individuals whereas many patients in primary care may often not be interested in receiving treatment for AUD. To this degree, studies examining primary care versus specialty care whereby there was comparable baseline contemplation or previous treatment history, similar or even improved alcohol outcomes were observed in the primary care group [e.g. 20]. This suggests that a null result in noninferiority trials can be perceived as supporting the recommendation for implementation of AUD treatment into primary care whereby the aim is to facilitate earlier uptake of treatment rather than determining a more effective setting for treatment in comparable patients.

\section{Conclusion}

Models of care in primary care-settings enhanced treatment uptake (psychosocial and/or pharmacotherapy) while the results for alcohol consumption were somewhat mixed. Our findings show that models of care in primary care-settings have promise to be beneficial in the management of AUD in terms of engagement. More studies are required with consistent outcome measures in order to determine effectiveness and cost effectiveness of these models of care, to clarify the most appropriate components of the models and to determine which patients are most suitable.

\section{Appendix 1}

\section{Search strategy MEDLINE}

Search strategy

- Draft of at least one database

\begin{tabular}{|c|c|c|}
\hline Concept & $\begin{array}{l}\text { Description of } \\
\text { concept }\end{array}$ & Research Terms \\
\hline A & $\begin{array}{l}\text { Primary Health } \\
\text { Care }(\mathrm{PHC})\end{array}$ & $\begin{array}{l}\text { exp Primary Health Care/ OR exp. General } \\
\text { Practice/ OR Primary Care.mp }\end{array}$ \\
\hline B & $\begin{array}{l}\text { Alcohol Use } \\
\text { Disorder }\end{array}$ & $\begin{array}{l}\text { exp Alcoholism/ ORexp. Alcohol Drinking/ } \\
\text { OR alcohol dependence.mp. OR alcohol } \\
\text { problems.mp. OR hazardous drinking.mp. } \\
\text { OR problem drinking.mp. OR AUD.mp }\end{array}$ \\
\hline C & Treatment & $\begin{array}{l}\text { exp disease management/ OR } \\
\text { treatment.mp. OR intervention.mp. }\end{array}$ \\
\hline D & Model of care & $\begin{array}{l}\text { models of care.mp. ORexp. Delivery of } \\
\text { Health Care, Integrated/ OR Patient Care } \\
\text { Team/ OR shared care.mp OR Collaborative } \\
\text { care.mp ORstepped care.mp. ORmulti- } \\
\text { faceted care.mp. ORInterdisciplinary } \\
\text { treatment approach.mp. OR nurse } \\
\text { practitioners/ OR exp. family nurse } \\
\text { practitioners/ OR exp. nurse specialists/ OR } \\
\text { specialist liaison.mp. OR Chronic Disease/ } \\
\text { OR Chronic Care.mp }\end{array}$ \\
\hline
\end{tabular}

- Search: A + B + C + D

\section{Appendix 2}

Search strategy grey literature

Grey matters: a practical tool for searching healthrelated grey literature [internet]. Ottawa, CADTH; 2018.

Terms used: alcohol, primary care, general practice. Most sites had a search engine but almost none allowed for an advanced search.

Grey Matters headings

- Health technology assessment agencies - all searched, some sites were useful

- International - all searched, some sites were useful (12 useful titles found)

- Health economics - not searched, not relevant - International - not searched, not relevant

- Clinical practice guideline - some searched, nothing found

- International - some searched, some results found ( 2 useful titles found) 
- Drug and Device Regulatory approvals - not searched, not relevant

- International - not searched, not relevant

- Advisories and warnings - not searched, not relevant

- International - not searched, not relevant

- Drug Class reviews - not searched, not relevant

- Clinical trial registries - searched, relevant titles found - same studies. 3 protocols and/or conference abstracts of potential useful studies found but no data available yet (emailed authors).

- Canadian drug formularies - not searched, not relevant

- Canadian physician Fees schedules - not searched, not relevant

- Databases - we searched Medline, PsycINFO, Cochrane database of systematic reviews, Cochrane Central Register of Controlled Trials (CENTRAL) and Embase (2019) - as described in the formal text.

- Health statistics - not searched, not relevant

- Search Engine - google and google scholar searched, this yielded a lot of hits. All useful titles were also found through our database search (55 useful titles, no new titles however). As recommended by Grey matters tool - I only went through the first 100 titles. As you cannot do a specific search in google, it yielded $>1500$ hits.

- Open access journals - searched, nothing found

- Behavioural change - searched, nothing found

- Natural medicine and environmental health - not searched, not relevant

- Dentistry - not searched, not relevant

- Diagnostic tests - not searched, not relevant

- Mental health - searched, site not working

- Nursing - not searched, not relevant

- Physiotherapy/ rehabilitation - not searched, not relevant

Total hits - unknown.

Useful titles -72 .

Useful titles after removing duplicates from main database search - 17 .

Full text read - 14 .

Used in systematic review - nil (some of the titles that were found in the google scholar search were used in the systematic review but these articles were also yielded by the database search).

\section{Abbreviations}

AST: Aspartate transaminase; ALT: Alanine aminotransferase; AUD: Alcohol use disorder; AUDIT: Alcohol Use disorders identification test; CBT: Cognitive behavioural therapy; CCM: Chronic care model; CENT RAL: Cochrane Central Register of Controlled Trials; DSM-IV: Diagnostic and statistical manual of mental disorders; EMR: Electronic medical record; GGT: $\gamma$-Glutamyltransferase; HDD: Heavy drinks per drinking day; ICD-10: International Statistical Classification of Diseases; IRR: Incidence rate ratios; MET: Motivational enhancement therapy; OAUD: Opioid and alcohol use disorder; OR: Odds ratio; PEth: PhosphatidylEthanol; PRIS MA: Preferred reporting items for systematic reviews and meta-analyses; PROSPERO: Prospective register of systematic reviews; RoB: Risk-of-bias; SBIRT: Screening, brief intervention and referral to treatment;

SD: Standard drinks; SMD: Standardized mean differences;

SUD: Substance use disorder; USA: United States of America;

WHO: World Health Organization

Acknowledgements

The authors report no acknowledgements.

Authors' contributions

SR and EL performed study selection and quality assessment. Disagreements were resolved through discussion and when necessary third party adjudication (KM). JC provided methodological consultation. SR interpreted the findings and wrote the manuscript with assistance from $\mathrm{KM}, \mathrm{PH}$ and RS. All authors read and approved the final manuscript.

\section{Funding}

Funding for this research was provided by the NSW Ministry of Health under the NSW Translational Early-Mid Career Fellowship Scheme (KM) and a NHMR C Practitioner Fellowship (PH). The contents are solely the responsibility of the individual authors and do not reflect the views of NSW Ministry of Health nor NHMRC, and nor did these funding bodies have any role in the design of the study, analysis, and interpretation of data and in writing the manuscript.

\section{Availability of data and materials}

Data that support the findings of this study are available from the corresponding author upon reasonable request.

Ethics approval and consent to participate

Not applicable.

Consent for publication

Not applicable.

\section{Competing interests}

The authors declare that they have no competing interests.

\section{Author details}

'Discipline of Addiction Medicine, Central Clinical School, Sydney Medical School, Faculty of Medicine and Health, The University of Sydney, Sydney, NSW 2006, Australia. ${ }^{2}$ Centre of Research Excellence in Indigenous Health and Alcohol, Central Clinical School, Faculty of Medicine and Health, The University of Sydney, Sydney, NSW 2006, Australia. ${ }^{3}$ Community Health Sciences, School of Public Health, Boston University, Boston, MA, USA. ${ }^{4}$ Drug Health Services, Royal Prince Alfred Hospital, Camperdown, NSW, Australia.

Received: 2 July 2020 Accepted: 15 October 2020

Published online: 05 December 2020

\section{References}

1. GBD 2016 Alcohol Collaborators. Alcohol use and burden for 195 countries and territories, 1990-2016: a systematic analysis for the Global Burden of Disease Study 2016. Lancet. 2018;392(10152):1015-35.

2. Wang PS, Lane M, Olfson M, Pincus HA, Wells KB, Kessler RC. Twelve-month use of mental health Services in the United States: results from the National Comorbidity Survey Replication. JAMA Psychiatry. 2005;62(6):629-40.

3. Rehm J, Allamani A, Elekes Z, Jakubczyk A, Manthey J, Probst C, et al. Alcohol dependence and treatment utilization in Europe - a representative cross-sectional study in primary care. BMC Fam Pract. 2015;16:90.

4. Morley KC, Logge W, Pearson SA, Baillie A, Haber PS. National trends in alcohol pharmacotherapy: findings from an Australian claims database. Drug Alcohol Depend. 2016;166:254-7.

5. Morley KC, Logge W, Pearson SA, Baillie A, Haber PS. Socioeconomic and geographic disparities in access to pharmacotherapy for alcohol dependence. J Subst Abus Treat. 2017;74:23-5.

6. Joudrey PJ, Kladney M, Cunningham CO, Bachhuber MA. Primary care engagement is associated with increased pharmacotherapy prescribing for alcohol use disorder (AUD). Addict Sci Clin Pract. 2019;14(1):19. 
7. Wang PS, Berglund PA, Olfson M, Kessler RC. Delays in initial treatment contact after first onset of a mental disorder. Health Serv Res. 2004;39(2): 393-416.

8. Edlund MJ, Booth BM, Han X. Who seeks care where? Utilization of mental health and substance use disorder treatment in two national samples of individuals with alcohol use disorders. J Stud Alcohol Drugs. 2012;73(4):635-46

9. Proudfoot $\mathrm{H}$, Teesson M, Australian National Survey of Mental $\mathrm{H}$, Wellbeing. Who seeks treatment for alcohol dependence? Findings from the Australian National Survey of mental health and wellbeing. Soc Psychiatry Psychiatr Epidemiol. 2002;37(10):451-6.

10. Wagner $\mathrm{EH}$. The role of patient care teams in chronic disease management. BMJ. 2000;320(7234):569-72.

11. Bertholet N, Daeppen JB, Wietlisbach V, Fleming M, Burnand B. Reduction of alcohol consumption by brief alcohol intervention in primary care: systematic review and meta-analysis. Arch Intern Med. 2005;165(9):986-95.

12. Kaner EF, Beyer F, Dickinson HO, Pienaar E, Campbell F, Schlesinger C, et al. Effectiveness of brief alcohol interventions in primary care populations. Cochrane Database Syst Rev. 2007(2):Cd004148. https://doi.org/10.1002/ 14651858.CD004148.pub4.

13. O'Donnell A, Anderson P, Newbury-Birch D, Schulte B, Schmidt C, Reimer J, et al. The impact of brief alcohol interventions in primary healthcare: a systematic review of reviews. Alcohol Alcoholism (Oxford). 2014;49(1):66-78.

14. Saitz R. Alcohol screening and brief intervention in primary care: absence of evidence for efficacy in people with dependence or very heavy drinking. Drug Alcohol Rev. 2010;29(6):631-40.

15. Saitz R. 'SBIRT' is the answer? Probably not. Addict (Abingdon). 2015;110(9): $1416-7$

16. Moher D, Liberati A, Tetzlaff J, Altman DG. Preferred reporting items for systematic reviews and meta-analyses: the PRISMA statement. Open Med. 2009;3(3):e123-30.

17. Rombouts SA, Conigrave J, Louie E, Haber P, Morley KC. Evidence-based models of care for the treatment of alcohol use disorder in primary health care settings: protocol for systematic review. Syst Rev. 2019;8(1):275.

18. Higgins JPT, Sterne, J.A.C., Savović, J., Page, M.J., Hróbjartsson, A., Boutron, I., Reeves, B., Eldridge, S. A revised tool for assessing risk of bias in randomized trials. In: Chandler, J., McKenzie, J., Boutron, I., Welch, V. (editors). Cochrane Methods. Cochrane Database of Systematic Reviews, 10 (Suppl 1). doi: https://doi.org/10.1002/14651858.CD201601. 2016.

19. Moore AA, Blow FC, Hoffing M, Welgreen S, Davis JW, Lin JC, et al. Primary care-based intervention to reduce at-risk drinking in older adults: a randomized controlled trial. Addiction (Abingdon). 2010;106(1):111-20.

20. Ettner SL, Xu H, Duru OK, Ang A, Tseng CH, Tallen $L$, et al. The effect of an educational intervention on alcohol consumption, at-risk drinking, and health care utilization in older adults: the project SHARE study. J Stud Alcohol Drugs. 2014;75(3):447-57.

21. Wallhed Finn S, Hammarberg A, Andreasson S. Treatment for Alcohol Dependence in Primary Care Compared to Outpatient Specialist Treatment-A Randomized Controlled Trial. Alcohol Alcoholism (Oxford). 2018;53(4):376-85

22. Drummond C, Coulton S, James D, Godfrey C, Parrott S, Baxter J, et al. Effectiveness and cost-effectiveness of a stepped care intervention for alcohol use disorders in primary care: pilot study. Br J Psychiatry. 2009; 195(5):448-56

23. Coulton S, Bland M, Crosby H, Dale V, Drummond C, Godfrey C, et al. Effectiveness and cost-effectiveness of opportunistic screening and stepped-care interventions for older alcohol users in primary care. Alcohol Alcohol. 2017:52(6):655-64

24. Oslin DW, Lynch KG, Maisto SA, Lantinga LJ, McKay JR, Possemato K, et al. A randomized clinical trial of alcohol care management delivered in Department of Veterans Affairs primary care clinics versus specialty addiction treatment. J Gen Intern Med. 2013;29(1):162-8.

25. Watkins KE, Ober AJ, Lamp K, Lind M, Setodji C, Osilla KC, et al. Collaborative Care for Opioid and Alcohol use Disorders in primary care: the SUMMIT randomized clinical trial. JAMA Intern Med. 2017;177(10):1480-8.

26. Upshur C, Weinreb L, Bharel M, Reed G, Frisard C. A randomized control trial of a chronic care intervention for homeless women with alcohol use problems. J Subst Abus Treat. 2015;51:19-29.

27. Bradley KA, Bobb JF, Ludman EJ, Chavez LJ, Saxon AJ, Merrill JO, et al. Alcohol-related nurse Care Management in Primary Care: a randomized clinical trial. JAMA Intern Med. 2018;178(5):613-21.
28. Saitz R, Cheng DM, Winter M, Kim TW, Meli SM, Allensworth-Davies D, et al. Chronic care management for dependence on alcohol and other drugs: the AHEAD randomized trial. JAMA. 2013;310(11):1156-67.

29. Willenbring $\mathrm{ML}$, Olson $\mathrm{DH}$. A randomized trial of integrated outpatient treatment for medically ill alcoholic men. Arch Intern Med. 1999;159(16): 1946-52.

30. Watkins KE, Setodji C, McCullough CM. Necessary Clarifications Concerning Results of the SUMMIT Trial-ReplyNecessary Clarifications Concerning Results of the SUMMIT Trial-ReplyLetters. JAMA Intern Med. 2018;178(3):429.

31. Bodenheimer T, Wagner EH, Grumbach K. Improving primary care for patients with chronic illness. JAMA. 2002;288(14):1775-9.

32. Bodenheimer T, Wagner EH, Grumbach K. Improving primary care for patients with chronic illness: the chronic care model, part 2. JAMA. 2002; 288(15):1909-14.

33. Von Korff M, Gruman J, Schaefer J, Curry SJ, Wagner EH. Collaborative management of chronic illness. Ann Intern Med. 1997;127(12):1097-102

34. Wagner EH, Austin BT, Von Korff M. Organizing care for patients with chronic illness. Milbank O. 1996;74(4):511-44.

35. Clifford PR, Davis CM. Alcohol treatment research assessment exposure: a critical review of the literature. Psychol Addict Behav. 2012;26(4):77381.

36. Daeppen J-B, Gaume J, Bady P, Yersin B, Calmes J-M, Givel J-C, et al. Brief alcohol intervention and alcohol assessment do not influence alcohol use in injured patients treated in the emergency department: a randomized controlled clinical trial. Addiction (Abingdon). 2007;102(8):1224-33.

37. Katon WJ, Lin EHB, Von Korff M, Ciechanowski P, Ludman EJ, Young B, et al. Collaborative Care for Patients with depression and chronic illnesses. N Engl J Med. 2010;363(27):2611-20.

38. Le KB, Johnson JA, Seale JP, Woodall H, Clark DC, Parish DC, et al. Primary care residents lack comfort and experience with alcohol screening and brief intervention: a multi-site survey. J Gen Intern Med. 2015;30(6):790-6.

39. McLellan AT, Starrels JL, Tai B, Gordon AJ, Brown R, Ghitza U, et al. Can Substance Use Disorders be Managed Using the Chronic Care Model? Review and Recommendations from a NIDA Consensus Group. Public Health Rev. 2014;35(2). http://www.journalindex.net/visit.php?j=6676.

40. Storholm ED, Ober AJ, Hunter SB, Becker KM, Iyiewuare PO, Pham C, et al. Barriers to integrating the continuum of care for opioid and alcohol use disorders in primary care: a qualitative longitudinal study. J Subst Abus Treat. 2017:83:45-54.

41. Food and Drug Administration. Alcoholism: Developing Drugs for Treatment (No. FDA D-0152-001). Silver Spring: Food and Drug Administration; 2015.

42. European Medicines Agency. Guideline on the Development of Medicinal Products for the Treatment of Alcohol Dependence. UK: European Medicines Agency; 2010

43. World Health Organization. International Guide for Monitoring Alcohol Consumption and Related Harm. Geneva: World Health Organization; 2000.

44. Witkiewitz K, Falk D, Litten R, Hasin D, Kranzler H, Mann K, et al. Maintenance of World Health Organization risk drinking level reductions and Posttreatment functioning following a large alcohol use disorder clinical trial. Alcoholism. 2019;3(5):979-87.

45. Knox J, Wall M, Witkiewitz K, Kranzler HR, Falk D, Litten $\mathrm{R}$, et al. Reduction in nonabstinent WHO drinking risk levels and change in risk for liver disease and positive AUDIT-C scores: prospective 3-year follow-up results in the U.S general population. Alcohol Clin Exp Res. 2018;42:2256-65.

46. Knox J, Scodes J, Wall M, Witkiewitz K, Kranzler HR, Falk DE, et al. Reduction in non-abstinent WHO drinking risk levels and depression/anxiety disorders: 3-year follow-up results in the US general population. Drug Alcohol Depend. 2019;197:228-35.

47. Hasin DS, Wall M, Witkiewitz K, Kranzler HR, Falk DE, Litten RZ, et al. Change in non-abstinent WHO drinking risk levels and alcohol dependence: a 3 year followup study in the US general population. Lancet Psychiatry. 2017:4:469-76.

48. Nutt DJ, Gual A, Anderson P, Rehm J. Why Less Is Always More in the Treatment of Alcohol Use Disorders. JAMA Psychiatry. 2019;76(4):359-360.

49. Falk D, O'Malley S, Witkiewitz $K$, Anton R, Litten R, Slater M, et al. Evaluation of drinking risk levels as outcomes in alcohol pharmacotherapy TrialsA secondary analysis of 3 randomized clinical trials. JAMA Psychiatry. 2019; 76(4):374-81.

50. Kwo PY, Cohen SM, Lim JK. ACG clinical guideline: evaluation of abnormal liver chemistries. Am J Gastroenterol. 2017;112:18-35. 
51. Bush KR, Kivlahan DR, McDonell MB, Finn SD, Bradley KA. The AUDIT alcohol consumption questions (AUDIT-C): an effective brief screening test for problem drinking. Ambulatory care quality improvement project (ACQUIP). Alcohol use disorders identification test. Arch Intern Med. 1998;158:1789-95.

52. Bradley KA, McDonell MB, Bush KR. The AUDIT alcohol consumption questions: reliability, validity, and responsiveness to change in older male primary care patients. Alcohol Clin Exp Res. 1998;22:1842-9.

53. Bradley KA, Kivlahan DR, Zhou XH, et al. Using alcohol screening results and treatment history to assess the severity of at-risk drinking in veterans affairs primary care patients. Alcohol Clin Exp Res. 2004;28:448-55.

54. Gaume J, Bertholet N, Daeppen JB. Readiness to change predicts drinking: findings from 12-month follow-up of alcohol use disorder outpatients. Alcohol Alcohol. 2017;52(1):65-71.

55. Rollnick S, Heather N, Gold R, Hall W. Development of a short 'readiness to change' questionnaire for use in brief, opportunistic inter-ventions among excessive drinkers. Br J Addict. 1992;87(5):743-54.

56. Maisto SA, Conigliaro J, McNeil M, Kraemer K, O'Connor M, Kelley ME. Factor structure of the SOCRATES in a sample of primary care patients. Addict Behav. 1999;24(6):879-92.

57. Epler AJ, Kivlahan DR, Bush KR, Dobie DJ, Bradley KA. A brief readiness to change drinking algorithm: concurrent validity in female VA primary care patients. Addict Behav. 2005:30(2):389-95.

58. Williams EC, Horton NJ, Samet JH, Saitz R. Do brief measures of readiness to change predict alcohol consumption and consequences in primary care patients with unhealthy alcohol use? Alcohol Clin Exp Res. 2007;31(3):428-35.

59. Canaway R, Boyle DI, Manski-Nankervis JE, Bell J, Hocking JS, Clarke K, et al. Gathering data for decisions: best practice use of primary care electronic records for research. Med J Aust. 2019;210(Suppl 6):S12-S6.

60. Raghupathi W, Raghupathi V. Big data analytics in healthcare: promise and potential. Health Inf Sci Syst. 2014;2:3.

61. Harrison KH, Lee KK, Dobbins T, Wilson S, Hayman N, Ivers R, et al. Supporting Aboriginal Community Controlled Health Services to deliver alcohol care: protocol for a cluster randomised controlled trial. BMJ Open 2019;9(11). https://doi.org/10.1136/bmjopen-2019-030909.

\section{Publisher's Note}

Springer Nature remains neutral with regard to jurisdictional claims in published maps and institutional affiliations.

Ready to submit your research? Choose BMC and benefit from:

- fast, convenient online submission

- thorough peer review by experienced researchers in your field

- rapid publication on acceptance

- support for research data, including large and complex data types

- gold Open Access which fosters wider collaboration and increased citations

- maximum visibility for your research: over $100 \mathrm{M}$ website views per year

At $\mathrm{BMC}$, research is always in progress.

Learn more biomedcentral.com/submissions 